\title{
A relação entre discurso, estrutura e história nos estudos da linguagem
}

\author{
Isabel MUNIZ-LIMA (D) \\ Universidade Federal do Ceará (PPGLIN/UFC/CAPES)
}

\section{RESUMO}

Nesta resenha da videoconferência do professor José Luiz Fiorin, realizada durante o evento Abralin Ao Vivo, apresentamos os pontos-chave das discussões e reflexões empreendidas pelo pesquisador. Em sua exposição, o professor enfatiza a importante relação entre forma e conteúdo para a análise de textos. Ao longo de sua apresentação, o pesquisador aborda um dos pensamentos fundamentais envolvendo os estudos da linguagem: o sentido não está no texto, mas ele surge na construção empreendida pelo leitor. Entre outros aspectos, o professor Fiorin explora o pensamento bakhtiniano sobre a linguagem e deixa clara a relação existente entre discurso, estrutura linguística e história.

EDITADO POR Raquel Freitag (PPGL/UFS)

REVISADO POR

Palmira Heine

DATAS

Recebido: 12/05/2020 Aceito: 01/06/2020 Publicado: 27/06/2020

COMO CITAR Muniz-Lima, I. (2020). A relação entre discurso, estrutura e história nos estudos da linguagem. Revista da Abralin, v. 19, n. 2 , p. 1-3, 2020.

\section{RESUMÉ}

Dans ce résumé de la conférence em ligne du professeur José Luiz Fiorin, tenue lors de l'événement "Abralin Ao Vivo", nous présentons les points clés des discussions et réflexions présentés par le chercheur. Dans sa présentation, le professeur souligne la relation importante entre la forme et le contenu pour l'analyse des textes. Tout au long de sa présentation, le chercheur aborde l'une des réflexions fondamentales de l'étude du langage: le sens n'est pas dans le texte, mais il apparaît dans la construction effectué par le lecteur. Entre autres aspects, le professeur Fiorin explore la réflexion bakhtinienne sur la langue et met en évidence la relation entre le discours, la structure linguistique et l'histoire. 


\title{
REVISTA DA ABRALIN
}

\author{
PALAVRAS-CHAVE
}

Discurso. Estrutura. História.

MOTS-CLÉS

Discours. Structure. Histoire.

A fala resenhada neste trabalho faz parte de uma série de transmissões ao vivo realizadas pela Associação Brasileira de Linguística (Abralin) em seu canal no Youtube, no período de maio a julho de 2020. Em 9 de maio de 2020, às 10h, o pesquisador José Luiz Fiorin apresentou videconferência com o tema "Discurso, estrutura e história"1.

O pesquisador inicia sua exposição dando destaque a um dos pensamentos fundamentais nos estudos da linguagem: o sentido não está no texto, mas é o leitor que o constrói. Desse modo, a leitura seria, não uma busca pela intenção do autor - este incapaz de controlar os sentidos que produz -, mas uma tentativa de rastrear a intenção daquilo que ele produz. Nessa perspectiva, Fiorin esclarece que o texto deve ser percebido, não só pela estrutura linguística, mas a partir da análise de seus processos de construção específicos. Assim, os procedimentos intrínsecos à forma composicional dos textos não são suficientes para alcançar seus sentidos, sendo preciso, portanto, que o leitor estabeleça ligação entre forma e conteúdo.

Na sequência de sua fala, Fiorin se debruça sobre o papel da linguagem. O pesquisador elucida que nossa relação com o real é sempre mediada pela linguagem, constituindo-se, portanto, projeção do mundo tangível. O próprio ato enunciativo, conforme esclarece o pesquisador, é, em si mesmo, uma comprovação de que não conseguimos alcançar o real sem a intervenção da linguagem.

A partir dessas discussões, a questão do dialogismo ganha relevo na fala do professor Fiorin. Nessa perspectiva, o pesquisador destaca que o ato de instauração de um eu e de um tu contribui para a percepção do dialogismo bakhtiniano, na medida em que esse ato confirma uma tomada de posição por parte do enunciador em relação às vozes que cruzam seu dizer.

Ao esclarecer que todo discurso é constituído a partir de outro e que, portanto, "deixa ver seu direito e seu avesso", o pesquisador reforça a atualidade do pensamento bakhtiniano. Para ilustrar a questão do dialogismo, Fiorin apresenta uma série de exemplos nos quais o embate de discursos se evidencia. O discurso racista, por exemplo, se constitui na medida em que dialoga sóciohistoricamente com o discurso antirracista. Antes focado na crença de que havia uma inferioridade ou hierarquia biológica entre seres humanos, o discurso racista precisou se modificar ao longo do tempo e passou a adotar, em contraposição à ideia de comunidade e miscigenação do discurso

1 Até a revisão final deste artigo, a transmissão da fala do professor Fiorin possuía 3.586 visualizações. É possível assistir ao conteúdo completo da fala do pesquisador e visualizar os comentários apresentados no chat acessando o canal da Abralin no Youtube. 


\section{REVISTA DA ABRALIN}

antirracista, a percepção de que as diferentes culturais entre as raças justificariam, portanto, a necessidade de uma segregação. Esse exemplo revela ainda, conforme esclarece Fiorin, a importância que Bakhtin imprime ao contexto sociohistórico ao tratar do dialogismo.

A transmissão ao vivo do professor José Luiz Fiorin é finalizada com a reafirmação de que todo texto apresentado ao leitor é, portanto, uma ilusão, pois atua como representação da subjetividade humana por meio da linguagem. Embora não se debruce sobre a válida discussão que envolve os conceitos de texto e de discurso na linguística, a fala do pesquisador contribui para que os estudiosos da linguagem percebam a relação intrínseca entre discurso, estrutura e história. Perceber essa confluência é, sem dúvidas, enriquecedor, pois possibilita alcançar as virtualidades dos textos.

\section{REFERÊNCIA}

DISCURSO, estrutura e história. Conferência apresentada por José Luiz Fiorin [s.l., s.n], 2020. 1 vídeo (1h 46min 01s). Publicado pelo canal da Associação Brasileira de Linguística. Disponível em: https:// https://youtu.be/GEoK4J61kOA. Acesso em: 09 mai 2020. 